\title{
Does the Environmental Internal Audit Impact the Achieving of Sustainable Development in Industrial Companies Listed on the Amman Stock Exchange?
}

\author{
Eman Ahmad Al Hanini ${ }^{1}$ \\ ${ }^{1}$ Department of Accounting, Faculty of Business, Balqa Applied University, Al Salt, Jordan \\ Correspondence: Eman Ahmad Al Hanini, Associate Professor, Department of Accounting, Faculty of Business, \\ Balqa Applied University, Al Salt, Jordan. E-mail: eman.hanini@bau.edu.jo
}

Received: October 27, 2020

Accepted: December 10, 2020

Online Published: January 20, 2021

doi:10.5430/ijfr.v12n3p220

URL: https://doi.org/10.5430/ijfr.v12n3p220

\begin{abstract}
This study aimed to determine the impact of environmental internal auditing with its dimensions represented by (compliance auditing, auditing environmental management systems, and auditing environmental financial statements) in achieving sustainable development in industrial companies listed on the Amman Stock Exchange. To achieve the aim of the study, a questionnaire was designed as a data collection tool for the study and distributed among 154 respondents namely: internal auditors, financial managers, and employees working in the financial departments in these companies. After conducting the necessary statistical analysis using SPSS, a statistical impact was reached at the significance level of $\alpha \leq 0.05$ for environmental internal auditing with its dimensions represented by (auditing compliance, auditing environmental management systems, and auditing environmental financial statements) in achieving sustainable development in industrial companies listed on the Amman Stock Exchange. The study suggests that industrial companies must provide appropriate environmental internal audit tools, including providing internal auditors with knowledge of environmental factors that have a fundamental impact on financial statements and understanding of environmental legislation and laws. The findings clarified the importance of training internal auditors on the stages of environmental internal auditing and skills in assessing environmental risks and obligations.
\end{abstract}

Keywords: environmental internal audit, sustainable development, industrial companies, Amman Stock Exchange

\section{Introduction}

Interest in the issue of protecting the environment as well as the natural and economic resources and preserving them for the benefit of the future generations has recently increased. Also known and called sustainable development by many groups, such as legislative bodies and associations for environmental protection. This culminated in creating an environmental and cultural awareness among companies, and pushed them to practice their work according to the requirements of environmental laws and legislations so that they fulfill their responsibilities towards the surrounding environment, which showed the need for environmental auditing in general and internal environmental audit, in particular (Lotfi, 2005). Given the fact that the industrial companies are the most affected and influenced by the environment and the importance of their role in preserving the environment from pollution as well as the role that the internal auditing play with its multiple and comprehensive dimensions of environmental auditing, the researchers sought to examine the impact of internal environmental audit in achieving sustainable development in the industrial companies listed in Amman Stock Exchange.

\subsection{Objectives of the Study}

The main objective of this study is to demonstrate the impact of internal environmental audit with all its aspects (compliance audit, environmental management systems audit, and environmental financial statements auditing) in achieving sustainable development in industrial companies listed on the Amman Stock Exchange.

\subsection{Hypothesis of the Study}

The null study hypotheses are represented as follows:

H01: There is no statistically significant impact at the level of $\alpha \leq 0.05$ for compliance audit to achieving sustainable development in industrial companies listed on the Amman Stock Exchange. 
H02: There is no statistically significant impact at the level of $\alpha \leq 0.05$ for auditing environmental management systems in achieving sustainable development in industrial companies listed on the Amman Stock Exchange.

H03: There is no statistically significant impact at the level of $\alpha \leq 0.05$ for environmental financial auditing in achieving development requirements in industrial companies listed on the Amman Stock Exchange.

\subsection{Problem and Questions of the Study}

Jordan is a country known for its limited natural and economic resources that are nowadays decreasing. Jordan's population is increasing at high rates, and arising from the natural increase due to the increase in birth rates and the decrease in death rates. Similarly, this unusual increase resulted from the migration of residents of surrounding countries due to wars and displacement. The industrial sector is a significant source of pollution in all its forms, and in view of contemporary challenges and the importance of everyone bears responsibility for preserving the environment, especially In light of the existence of internal audit committees in industrial companies, it is hoped that environmental internal audit procedures will be carried out to contribute to achieving sustainable development. The problem of the study was represented by the following main question: Is there an impact of internal environmental audit in achieving sustainable development in industrial companies listed on the Amman Stock Exchange? The current study is carried out to answer the questions below:

1- Is there a statistically significant impact at $\alpha \leq 0.05$ level for compliance audit to achieving sustainable development in industrial companies listed on the Amman Stock Exchange?

2- Is there a statistically significant impact at $\alpha \leq 0.05$ level for auditing environmental management systems in achieving sustainable development in industrial companies listed on the Amman Stock Exchange?

3 - Is there a statistically significant impact at $\alpha \leq 0.05$ level for environmental financial auditing in achieving sustainable development in the industrial companies listed on the Amman Stock Exchange?

1.4 The Model of the Study

Independent variable

Environmental Internal Audit

-Compliance audit

-Environmental management systems auditing

-Environmental financial auditing

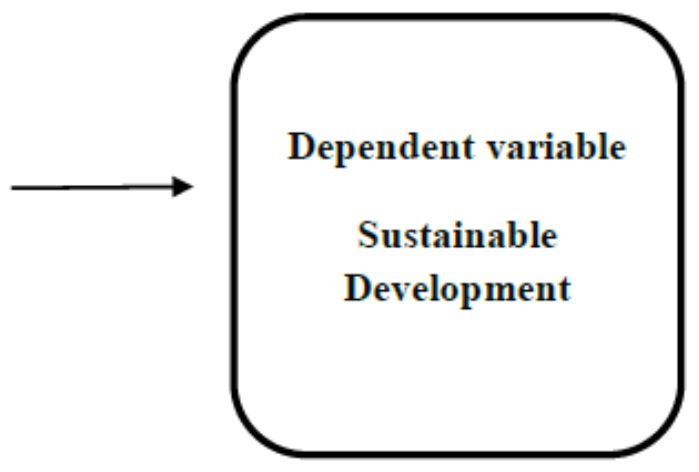

* The model is developed by the researcher using the study (Izat, 2019) and (Hayek, 2013)

\section{Theoretical Framework}

\subsection{Environmental Internal Audit: Types and Objectives}

It can be defined as the process of examining, evaluating and assuring that the company has complied with the requirements that help in preserving the surrounding environment from pollution. The audit task is accomplished by a neutral party who obtains appropriate evidence and evaluates it to ensure that the organization does not commit acts that affect the environment (Al-Hayek, 2013). It is also known as evaluating the results of implementing national and local policies, plans and programs in the field of protecting and improving the environment and measuring the impact of the organization's operations on the environment in accordance with the approved standards and indicating the cost if possible (Izat, 2019).

As for the objectives of environmental auditing, Srataj (2010) believes that there is a need to audit environmental performance in order to determine the quantitative and qualitative stress that occurs to the environment and resources, and this is done through (Environmental Quality Authority, 2014) as indicated below: 
1- Objective assessment of the environmental performance of the company.

2- Ensure that the environmental requirements or obligations imposed by laws and legislation issued by the specialized authorities are fulfilled.

3- Preparing reports of the environmental status to who it may concern.

4- Examine and evaluate the actual performance and compare it with standards and programs, and report environmental problems in a timely manner.

5- Predicting potential environmental risks and preparing for their removal or treatment.

6- Ensuring the effectiveness of environmental management systems and the appropriateness of control methods so that errors are discovered and violations avoided.

Environmental internal audit has three types (Ba'ajaja, 2012) (Sameer, 2017) (Dreibati, 2009):

1- Compliance audit: It is the most common audit in the industrial sector, and it means reviewing the level of the industrial company's compliance with environmental legislation and laws and not violating them. This is in order to avoid companies bearing civil and criminal liability that may arise due to these violations and prevent the financial obligations and losses that the company incurs as a result of the negligence in the application of these legislations and laws.

2- Environmental management systems audit: The environmental management system is crucial as it expresses the structure that defines responsibilities, policies, practices, procedures and processes necessary to protect the environment and manage environmental issues. This system is considered part of the internal management control structure of the facility that aims to provide information related to identifying and assessing risks that the company is exposed to when practicing its activities or presenting its product. Likewise, it determines the corrective measures that the company must take to improve the environmental performance.

3- Environmental financial audit: it is the audit related to environmental liabilities, costs and the reasonableness of estimates, and auditing of the appropriateness of the method used to disclose these liabilities in the financial statements.

\subsection{Sustainable Development and Its Objectives}

Sustainable development is defined as the maintenance and sustainability of natural resources in the environment to meet people's current economic and social needs, and manage them with advanced technology at the same time ensuring the continuation of their well-being for future generations (Abbas, 2010). And it depends on long-term strategies in the resources and their preservation, as they are the property of successive generations and they have the right to use and exploit them without wasting or depleting them (De'abs, 2006).

The basic goals of sustainable development are based on:

1- Environmental goals related to the preservation of biological diversity and the capacity of the environment so it can meet the requirements of future generations and the need for concerted efforts in addressing global issues related to pollution.

2- Economic goals concerning the economic growth, equality of income among individuals, and efficiency in using economic resources in order to preserve them.

3- Social goals regarding empowering community members and women in particular, and granting them basic rights of education, health, and their participation in various decisions (Doglas, 2000)

\subsection{Aspects of Sustainable Development}

The aspects of sustainable development are represented by four interdependent and complementary elements as follows (Harfosh, 2008) (Khababa, 2008) (Shalaby and Tayar, 2010) (Sameer, 2017) (Shareef, 2007):

1- The economic dimension is concerned of increasing the per capita share of economic resources, preventing the waste of natural resources, and holding economically developed countries responsible for limiting pollution and addressing its effects.

2- The social dimension provides people with health and educational services as well as safety standards and respect for human rights. It includes stabilizing population growth, maintaining the population distribution between the countryside and the city, increasing interest in providing the right to education and health insurance for all members of society. It also focuses on the interest in empowering Women and gives them their rights. 
3- The environmental dimension aims to rationalize the use of renewable and non-renewable environmental resources in the production processes, and include preserving agricultural lands, not excessive use of fertilizers and pesticides, which leads to pollution of surface and ground water, preserving natural resources on which agriculture depends, such as water lines, and the creation and adoption of Advanced agricultural practices and technologies to reduce pollution, protect the climate from global warming, and preserve the seas, oceans and coasts.

4- The technological aspect necessitates using cleaner technology in industrial facilities with reducing environmental pollution to a minimum, recycling waste and reducing energy. It represents the importance of the state adopting laws and prohibitive legislation related to the mandatory use of companies for clean technological means, and caution when using fuels in factories being a major source of air pollution when it is burned, and the rise in the earth's temperature, as well as the importance of preserving the ozone layer.

\subsection{Literature Review}

There are a number of research studies that fall within the scope of the current study. One of them is Stanescu's et al., study (2020) entitled "Environmental Audit Contribution to the Evaluation and Control of Environmental Information" was prepared to present the contribution of environmental audit on the evaluation and controlling the environmental information, and to identify the importance of environmental audit in economic entities in reducing environmental costs and recognizing the sanctions for industrial accidents with environmental and human impacts, the researchers used the description analysis, they depend on the previous scientific papers in this field.

Eremeeva's study (2020) with title "Audit of Future Environmental in Financial Statements" aimed to develop a methodology to audit financial statements and assess the reliability of the information which presented future events connected with environmental features. The study concluded that auditors should use a method focus on environmental factors and interconnection between financial process and economic factors.

Izat's study (2019) entitled 'Reflection of the Application of Environmental Auditing to Support the Process of Sustainable Development - Study in a Sample of Industrial Companies in the Kurdistan Region of Iraq' which aimed to define the role of environmental auditing in achieving a sustainable environment, as the study sample included 63 respondents from academics and workers in the accounting department in Iraqi industrial companies. The study concluded that environmental auditing reflects positively on sustainable development. The study recommended companies to conduct environmental auditing in addition to financial auditing.

Sameer's study (2017) with title "The Role of Environmental Audit in Achieving Sustainable development in Adrar / Algeria" was designed to determine the role of environmental auditing in achieving the requirements of sustainable development in Adrar city in Algeria. The study sample included financial managers, accountants and internal auditors working in industrial companies. The study concluded that there is no commitment to environmental legislation in the state, while there is a role for auditing systems Environmental management and auditing environmental financial statements in achieving sustainable development requirements. The study recommended the importance of adopting international standards for environmental internal auditing.

Hayek study (2013) entitled "Internal Environmental Audit in Jordanian Manufacturing Companies" identifies the extent of internal auditors in Jordanian industrial companies and the extent of their awareness of the importance of environmental internal auditing. The study sample included 125 internal auditors working in industrial companies. The study concluded that internal auditors do not realize the importance of environmental internal auditing, nor do they apply it. The study recommended the necessity for the official regulatory authorities in Jordan to enact laws and legislation binding on companies to conduct internal environmental auditing.

A study (Ba'ajaja, 2012) entitled "Environmental Audit from the Perspective of the Internal Auditors / An Analytical Study on Saudi Cement Companies' focused on identifying the internal auditors' point of view regarding the possibility of environmental internal auditing for economic units in Saudi Arabia. The study sample included 78 internal auditors working in Saudi cement companies. The study concluded that there are difficulties facing internal auditors when carrying out their work related to the administration of the facility and in the internal audit department. The study recommended the importance of passing legislation related to environmental internal auditing.

Dosary (2011) aimed to demonstrate the importance of environmental cost accounting in improving the quality of accounting information in Kuwaiti industrial companies. The study sample included 105 respondents from financial managers and workers in Kuwaiti industrial companies. The study concluded that there is an effect of environmental cost accounting on improving the quality of financial information, and an impact of senior management's commitment to environmental standards in improving the quality of accounting information. The study recommended that industrial companies should apply environmental accounting. his study aimed to define the role of 
internal auditing in evaluating environmental performance, as the study community was represented by financial managers and internal auditors in Syrian industrial companies. The study concluded that internal auditors do not evaluate the environmental performance of industrial companies, and the study recommended the importance of establishing an association for internal auditors in Syria. And universities teach internal environmental auditing within courses.

Dreibi (2009) his study aimed to define the role of internal auditing in evaluating environmental performance, as the study community was represented by financial managers and internal auditors in Syrian industrial companies. The study concluded that internal auditors do not evaluate the environmental performance of industrial companies, and the study recommended the importance of establishing an association for internal auditors in Syria. And universities teach internal environmental auditing within courses.

Al-Zu'bi et al. (2006) attempted to demonstrate the possibility of applying environmental auditing in Jordan, by identifying the requirements, effects and limitations of the application, which were applied to three categories: academics, auditors and managers of industrial companies. Your sentence could be clearer. Consider the following paraphrase: Descriptive statistics and nonparametric tests are used in the research, especially the Kruskal-Wallis test. The study found that there are statistically significant differences in the average of the respondents' answers regarding the requirements of applying environmental auditing in Jordan, and the expected effects it has on the state, society and the company. The study recommended that the organizers of the accounting profession in Jordan should pay attention to environmental auditing,

\subsection{How Is the Current Study Different?}

This study was distinguished from the studies of (Samir, 2017), (Al-Dosary, 2011), (Ba'ajaja, 2012) and (Dreibi, 2009) in that it was applied in Jordan, while previous studies were applied in Syria, Iraq, Saudi Arabia and Algeria. Likewise IT differs from (Izat, 2019), (Al-Hayek, 2013), and (Al-Zu'bi et al.,, 2006) This study is unique in linking independent variables and dependent variables, because these studies only involve one or two issues, and do not involve determining the relationship or impact between environmental internal audit and sustainable environment.

\section{Methodology}

\subsection{Data Collection}

The study data were collected through primary sources represented by the questionnaire as a study tool. The questionnaire was designed based on previous studies that dealt with environmental internal auditing and the sustainable environment. Additionally data were also collected from secondary sources like books, scientific journals and relevant Internet sources.

\subsection{Population and Sample Study}

The population of this study was taken from 45 industrial companies listed on the Amman Stock Exchange. The sample unit consisted of employees of the financial department, financial managers and internal auditors working in these companies. As for the study sample, it was a simple random sample consisting of 154 respondents. 175 questionnaires were distributed among these employees.154 questionnaires were valid, i.e. 87\%, and it was confirmed that the size of the sample that was completed. This was based on the study of (Sekaran, \& Bougie, 2016, 295).

Table 1. Description of the study sample

\begin{tabular}{|c|c|c|c|}
\hline & ption & Frequency & Percentage \\
\hline \multirow{5}{*}{ Age } & Less than 25 years & 14 & $9 \%$ \\
\hline & $25-35$ years & 39 & $25 \%$ \\
\hline & $36-45$ years & 62 & $40 \%$ \\
\hline & More than 45 years & 39 & $26 \%$ \\
\hline & Total & 154 & $100 \%$ \\
\hline \multirow[b]{2}{*}{ Qualification } & Diploma & 12 & $8 \%$ \\
\hline & Bachelor & 130 & $84 \%$ \\
\hline
\end{tabular}




\begin{tabular}{lccc}
\hline & Master & 10 & $7 \%$ \\
\cline { 2 - 4 } & PHD & 2 & $1 \%$ \\
\cline { 2 - 4 } Experience & Total & 154 & $100 \%$ \\
\cline { 2 - 4 } & Less than 3 years & 15 & $10 \%$ \\
\cline { 2 - 4 } & $1-\quad 6$ years & 81 & $52 \%$ \\
\cline { 2 - 4 } Position & $1-\quad 14$ years & 42 & $27 \%$ \\
\cline { 2 - 4 } & More than 14 years & 16 & $11 \%$ \\
\cline { 2 - 4 } & Total & 22 & $100 \%$ \\
\cline { 2 - 4 } & Financial manager & 43 & $28 \%$ \\
\cline { 2 - 4 } & Internal auditor & 154 & $100 \%$ \\
\hline
\end{tabular}

Table 1 shows a description of the study sample which includes different age groups mainly between 36-45 years and their percentage reached $40 \%$ of the sample size. This age group represents the age of wisdom and experience and greater ability to evaluate and judge. The study sample included various qualifications focused on the bachelor's degree holders whose percentage reached $84 \%$ of the sample size. The table shows the availability of suitable practical experiences in the sample. The percentage of respondents whose experience exceeds 4 years is $90 \%$ of the sample size.

\section{Statistical Analysis of Data}

\subsection{Data Analysis and Discussion}

A set of statistical methods were used to analyze the data and test the hypotheses of the study. They are as follows:

1- Descriptive Statistic Measures: they included frequencies and percentages to describe the study sample namely arithmetic mean and standard deviation for analyzing the sample answers (Abu Zaid, 2018). Table No. 1 showed a description of the study sample and Table No. 2 demonstrated the mean and standard deviation of the items of the questionnaire representing the study variables. It is clear from the statistical analysis that all the paragraphs and variables of the study have an arithmetic mean greater than 3 which implies their acceptance. The standard deviation is less than 1 , and this indicates the plausibility and acceptance of the dispersion of the data (Bani Younes, 2017).

Table 2. The arithmetic mean and standard deviation of the paragraphs of the questionnaire

\begin{tabular}{|c|c|c|c|}
\hline No & Paragraphs & $\begin{array}{l}\text { Arithmetic } \\
\text { Mean }\end{array}$ & $\begin{array}{l}\text { Standard } \\
\text { Deviation }\end{array}$ \\
\hline \multicolumn{4}{|c|}{ Independent Variable (Environmental Internal Audit) } \\
\hline \multicolumn{4}{|c|}{ Compliance Audit } \\
\hline 1 & $\begin{array}{l}\text { The internal auditor has adequate knowledge of the environmental } \\
\text { legislation and laws in force in Jordan. }\end{array}$ & 3.94 & 0.588 \\
\hline 2 & $\begin{array}{l}\text { The company adheres to the environmental laws and legislations in } \\
\text { force in Jordan. }\end{array}$ & 3.90 & 0.817 \\
\hline 3 & $\begin{array}{l}\text { The administration holds the employee responsible for any breach or } \\
\text { violation of environmental legislation and laws. }\end{array}$ & 3.72 & 0.752 \\
\hline 4 & The company obtains licenses to own biological assets. & 3.94 & 0.941 \\
\hline 5 & $\begin{array}{l}\text { The company is keen not to commit violations and violations to avoid } \\
\text { fines and violations. }\end{array}$ & 3.85 & 0.636 \\
\hline 6 & The company is constantly updating its information related to & 3.91 & 0.792 \\
\hline
\end{tabular}




\begin{tabular}{|c|c|c|c|}
\hline \multicolumn{4}{|c|}{ restricted activities and areas. } \\
\hline 7 & $\begin{array}{l}\text { The company is keen to adhere to meeting societal claims related to } \\
\text { the environment and society. }\end{array}$ & 3.41 & 0.885 \\
\hline \multicolumn{2}{|c|}{ The arithmetic mean and standard deviation of all compliance audit paragraphs } & 3.81 & 0.486 \\
\hline \multicolumn{4}{|c|}{ Environmental Management Systems Audit } \\
\hline 8 & $\begin{array}{l}\text { The company's management is keen to establish an internal control } \\
\text { system that takes care of the company's environmental performance. }\end{array}$ & 3.95 & 0.677 \\
\hline 9 & $\begin{array}{l}\text { The management of the company provides the necessary resources to } \\
\text { implement and monitor the environmental management system. }\end{array}$ & 4.07 & 0.597 \\
\hline 10 & $\begin{array}{l}\text { The company's management seeks to obtain international standards } \\
\text { for environmental performance. }\end{array}$ & 3.8 & 0.639 \\
\hline 11 & $\begin{array}{l}\text { The company's management announces the environmental policies } \\
\text { that must be followed and duly documented. }\end{array}$ & 3.83 & 0.801 \\
\hline 12 & $\begin{array}{l}\text { The company reviews its activities and products to ensure that it does } \\
\text { not commit any threat to the environment or society. }\end{array}$ & 3.98 & 0.683 \\
\hline 13 & $\begin{array}{l}\text { The company's management announces the environmental errors that } \\
\text { the company may be exposed to, and the corrective measures that } \\
\text { must be followed to address these errors. }\end{array}$ & 3.97 & 0.782 \\
\hline 14 & $\begin{array}{l}\text { The company ensures that the employees in charge of managing } \\
\text { environmental systems receive the necessary qualification and } \\
\text { training. }\end{array}$ & 3.47 & 0.874 \\
\hline \multicolumn{2}{|c|}{$\begin{array}{l}\text { The company's management is keen to establish an internal control system that } \\
\text { takes care of the company's environmental performance. }\end{array}$} & 3.867 & 0.437 \\
\hline \multicolumn{4}{|c|}{ Environmental Financial Audit } \\
\hline 15 & $\begin{array}{l}\text { Ensure that environmental costs are disclosed in the financial } \\
\text { statements in the correct manner. }\end{array}$ & 4.01 & 0.292 \\
\hline 16 & $\begin{array}{l}\text { The disclosure of environmental liabilities in the financial statements } \\
\text { is made with credibility. }\end{array}$ & 3.44 & 0.572 \\
\hline 17 & $\begin{array}{l}\text { The company prepares special reports to show deviations of } \\
\text { environmental performance from environmental management plans. }\end{array}$ & 3.69 & 0.737 \\
\hline 18 & $\begin{array}{l}\text { Difficulties and problems of disclosure and accounting measurement } \\
\text { of some environmental costs are disclosed. }\end{array}$ & 4 & 0.459 \\
\hline 19 & $\begin{array}{l}\text { Any costs related to international or local certificates related to } \\
\text { environmental conservation shall be disclosed. }\end{array}$ & 3.91 & 0.491 \\
\hline \multicolumn{2}{|c|}{$\begin{array}{l}\text { The arithmetic mean and standard deviation for all environmental financial audit } \\
\text { paragraphs }\end{array}$} & 3.810 & 0.358 \\
\hline \multicolumn{4}{|c|}{ Dependent Variable (Sustainable Development) } \\
\hline 20 & $\begin{array}{l}\text { The company is constantly updating the methods of obtaining } \\
\text { resources in order to achieve sustainable development. }\end{array}$ & 3.92 & 0.634 \\
\hline 21 & $\begin{array}{l}\text { The company rationalizes the use of water, energy and other resources } \\
\text { while carrying out its production activities. }\end{array}$ & 3.92 & 0.697 \\
\hline 22 & $\begin{array}{l}\text { The company carries out continuous campaigns to raise awareness of } \\
\text { the importance of preserving natural resources inside and outside the } \\
\text { company. }\end{array}$ & 3.84 & 0.689 \\
\hline 23 & $\begin{array}{l}\text { The company is working on adopting modern technologies to reduce } \\
\text { and treat the pollution that may cause it. }\end{array}$ & 3.97 & 0.688 \\
\hline 24 & $\begin{array}{l}\text { The company contributes to encouraging education and providing job } \\
\text { and training opportunities for members of society. }\end{array}$ & 3.98 & 0.765 \\
\hline
\end{tabular}


25 The company works to provide appropriate health insurance for all its

3.71

0.834 employees.

26 The company conducts continuous maintenance of the company's assets to increase its efficiency and ensure that resources are not 3.84 0.689 wasted.

\begin{tabular}{clcc}
\hline 27 & $\begin{array}{l}\text { The company deals with caution when dealing with fuels to ensure } \\
\text { that the ozone layer is not damaged. }\end{array}$ & 3.68 & 0.943 \\
\hline 28 & $\begin{array}{l}\text { The company is keen to recycle waste to be used in production } \\
\text { processes. }\end{array}$ & 3.76 & 0.866 \\
\hline 29 & $\begin{array}{l}\text { The company is interested in empowering women, giving them the } \\
\text { appropriate opportunity to train and work, and benefit from their } \\
\text { experiences in rationalizing the use of resources. }\end{array}$ & 3.68 & 0.943 \\
\hline $\begin{array}{l}\text { The arithmetic mean and standard deviation for all sustainable environment } \\
\text { paragraphs }\end{array}$ & 3.830 & 0.421 \\
\hline
\end{tabular}

2- Inferential Statistic: where the Statistical Program for Social Sciences (SPSS) was conducted as follows:

1. The Cronbach Alpha test used to measure the internal consistency of the study's questionnaire, which has reached $90 \%$. Since it is greater than $70 \%$, this indicates that the study tool is stable, and that the collected data is appropriate for measuring variables, and can be relied upon to perform statistical analysis (Sekaran \& Bougie, 2016).

2. Skewness test, torsion factor and One-Sample Kolmogorov-Smirnov Test was used to identify whether the data fall within the normal distribution or not. It has been concluded that the data are normally distributed.

3. Multiple Linear Regression test to test the effects of independent variables on the dependent variable (Hair et.al.2018).

Table 3. The Multiple Regression Test

\begin{tabular}{|c|c|c|c|c|c|c|}
\hline \multirow{2}{*}{ 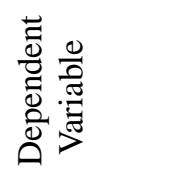 } & \multirow{2}{*}{$\begin{array}{l}\text { Independent variable } \\
\text { Internal ) } \\
\text { (Environmental Audit }\end{array}$} & \multicolumn{2}{|c|}{$\begin{array}{l}\text { Unstandardized } \\
\text { Coefficients }\end{array}$} & \multirow{2}{*}{$\begin{array}{c}\begin{array}{c}\text { Standardized } \\
\text { Coefficients }\end{array} \\
\text { Beta }\end{array}$} & \multirow{2}{*}{$\begin{array}{l}\text { The } \\
\text { computed } \\
\text { (T) value }\end{array}$} & \multirow{2}{*}{ T. Sig } \\
\hline & & $\mathrm{B}$ & Std. Error & & & \\
\hline \multirow{4}{*}{ 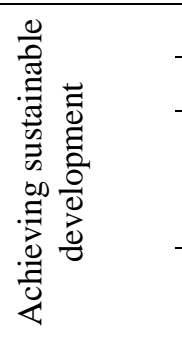 } & (Constant & .357 & .187 & & & \\
\hline & Compliance audit & .523 & .051 & .604 & 10.319 & .000 \\
\hline & $\begin{array}{l}\text { Environmental } \\
\text { management systems } \\
\text { audit }\end{array}$ & .204 & .054 & .211 & 3.800 & .000 \\
\hline & $\begin{array}{l}\text { Environmental } \\
\text { financial audit }\end{array}$ & .182 & .064 & .155 & 2.827 & .005 \\
\hline \multicolumn{2}{|c|}{$\begin{array}{ll}\text { Correlation } & \text { Determ } \\
\text { coefficient R }\end{array}$} & efficie & & \multicolumn{2}{|c|}{ The computed $F$ value } & F. Sig \\
\hline \multirow[t]{2}{*}{0.873} & \multicolumn{3}{|c|}{0.762} & 159.04 & & 0 \\
\hline & & & & & \multicolumn{2}{|c|}{ (Significant at $(0.05 \geq \alpha$ * } \\
\hline \multicolumn{2}{|c|}{ (Tabular $\mathrm{F}$ value $=(2,601$} & \multicolumn{2}{|r|}{$\mathrm{DF}=3 / 150$} & & \multicolumn{2}{|c|}{$($ Tabular $\mathrm{T}$ value $=(1.96$} \\
\hline
\end{tabular}

Table 3 shows the results of the statistical test for the study model that includes the independent variable of internal 
environmental auditing represented by (compliance auditing, auditing environmental management systems, auditing environmental financial statements) and one dependent variable representing the achievement of sustainable development in industrial companies listed on the Amman Stock Exchange. The correlation coefficient $\mathrm{R}=(0.873)$ indicates a strong relationship between internal environmental auditing in its dimensions and achieving sustainable development in the industrial companies listed on the Amman Stock Exchange.

It was also found that there is a statistically significant impact of the internal environmental audit on the dependent variable achieving sustainable development, through the value of (F. Sig) of (0.00) which is less than (0.05) and also through the value of $(\mathrm{F})$ calculated and its value is (159.04). The latter is greater than Its tabular value (2.60). This implies the significance of this model at the degree of freedom (3/150), and the value of the coefficient of determination $(\mathrm{R} 2=0.762)$ indicates that the internal audit in its dimensions justified $(76.2 \%)$ of the variance of sustainable development.

\subsection{Hypotheses Testing}

H01: There is no statistically significant impact at $\alpha \leq 0.05$ for auditing commitment to achieving sustainable development in industrial companies listed on the Amman Stock Exchange.

Table 3 shows that the value of the beta coefficient for this hypothesis related to the compliance audit is $(\beta=0.604)$ and the value of $(\mathrm{T})$ computed (10.319) is greater than its tabular value (1.96) at the level of $(\mathrm{Sig}=0.0)$ which is significant. This leads to rejecting the null hypothesis and accepting the alternative hypothesis that includes the existence of a statistically significant effect at the level of $\alpha \leq 0.05$ to audit the commitment to achieving the requirements of sustainable development in the industrial companies listed on the Amman Stock Exchange.

H02: There is no statistically significant impact at the level of $\alpha 0.05$ for auditing environmental management systems in achieving sustainable development in industrial companies listed on the Amman Stock Exchange.

Table No. 3 shows that the value of the beta coefficient for this hypothesis related to the audit of environmental management systems is $(\beta=0.604)$ and that the value of $(\mathrm{T})$ calculated (10.319) is greater than its tabular value (1.96) at the level of $(\mathrm{Sig}=0.0)$ which is significant. This means rejecting the null hypothesis and accepting the alternative hypothesis that includes a statistically significant effect at the level of $\alpha \leq 0.05$ for auditing environmental management systems in achieving sustainable development in industrial companies listed on the Amman Stock Exchange.

H03: There is no statistically significant impact at the level of $\alpha \leq 0.05$ for environmental financial auditing in achieving sustainable development in the industrial companies listed on the Amman Stock Exchange.

Table No. 3 showed that the value of the beta coefficient for this hypothesis related to environmental financial auditing reached $(\beta=0.155)$ and that the value of $(\mathrm{T})$ calculated $(2.827)$ is greater than its tabular value at the level of $(\mathrm{Sig}=0.005)$, which is significant. This means rejecting the null hypothesis and accepting the alternative hypothesis that includes a statistically significant effect at the level of $\alpha \leq 0.05$ in achieving sustainable development in the industrial companies listed on the Amman Stock Exchange.

\section{Conclusion and Recommendation}

The study found a statistically significant impact of internal environmental auditing with all its aspects (auditing compliance, auditing environmental management systems, and auditing environmental financial statements) on achieving sustainable development in industrial companies listed on the Amman Stock Exchange from the viewpoint of the respondents. The finding of the current research is in agreement with the Izat (2019) and Sameer (2017). This means that companies should focus on developing and supporting internal audit. Therefore, the researcher recommends industrial companies to provide appropriate environmental internal audit tools that provide internal auditors with knowledge of environmental factors that fundamentally affect the financial statements. These tools will familiarize them with environmental legislation and laws. The study also stresses the importance of training internal auditors on the stages of environmental internal auditing, and on specialized skills in assessing environmental risks and obligations. The companies should choose appropriate evaluation indicators for sustainable development that are clear, applicable, measurable and predictable. Internal auditors should be involved in this matter.

\section{References}

Abbas, S. (2010). Sustainable Development in the Arab World. University Youth Foundation, Alexandria, Egypt.

Abu Zaid, M. (2018). Statistical Analysis of Data Using SPSS (1st ed.). Dar Al- Safa'a, Amman, Jordan.

Ba'ajaja, S. (2012). Environmental Audit from the Perspective of the Internal Auditors/ An Analytical Study on Saudi 
Cement Companies. Scientific Journal of Azhar University, 8(10), 72-120.

Bani Younes, A. (2017). The beginner guide to general curricula in scientific research (1st ed.). Dar Al- Nafa'as, Amman, Jordan.

De'abs, Y. (2006). Environment and Sustainable Development. Al- Jalal Library, Alexandria, Egypt.

Doglas, M. (2000). Principles of Sustainable Development, translated by Shaheen, Baha'a. International Foundation, Cairo, Egypt.

Dosary, A. (2011). The Importance of Environmental Costs in Improving the Quality of Accounting Information (A field Study on the Industrial Companies Enlisted at Kuwait Stock Exchange). Unpublished thesis of master, Middle East University, Jordan.

Dreibati, R. (2009). The Role of Internal Auditing in Environmental Performance Evaluation. Unpublished thesis of master, Teshreen University, Syria.

Environmental Quality Authority. (2014). Guide of Environmental Audit Procedures. Palestine.

Ereemeva, O. (2020). Audit of Future Environmental in Financial Statements. Espacios, 41(7), 30-45.

Hair, J. F., Black, W. C., Babin, B. J., Anderson, R. E., \& Tatham, R. L. (2018). Multivariate Data Analysis (8th ed.). Cengage Learning EMEA.

Harfoosh, S. (2008). Conceptual Framework of Comprehensive Sustainable Development. Unpublished Paper Presented to the Sustainable Development Conference, Satef, Algeria.

Hayek, A. (2013). Internal Environmental Audit in Jordanian Manufacturing Companies. Derasat (Administrative Sciences), 40(2), 394-408.

Izat, R. (2019). Reflection of the Application of Environmental Auditing to Support the Process of Sustainable Development - Study in a Sample of Industrial Companies in the Kurdistan Region of Iraq,.Journal of Al Anbar, 26(11), 368-398.

Khababa, A. (2008). The Comprehensive Sustainable Development - Principles and Implementation. Unpublished Paper Presented to the Sustainable Development Conference, Satef, Algeria.

Lotfi, A. (2005). Different Audit for Different Purposes. Aldar Al Jamaia, Alexandria, Egypt.

Sameer, W. (2017). The Role of Environmental Audit in Achieving Sustainable development in Adrar/ Algeria. Unpublished thesis of master, Ahmad Draya University, Algeria.

Sartaj, A. (2010). Environmental Survey and Environmental Audit for Achieving Industrial Sustainable Development. Unpublished paper presented to the Regional Conference for Sudanese Industry, Sudan.

Sekaran, U., \& Bougie, R. (2016). Research Methods for Business: A Skill Building Approach (7 $7^{\text {th }}$ ed.). NY: John Wiley \& Sons Inc., New York.

Shalaby, A., \& Tayar, A. (2010). The Sustainable Development in the Algerian Economy (1st ed.). Sakekda, Algeria.

Shareef, O. (2007). The Use of Renewable Energy and its Role in Sustainable Development. Unpublished PhD thesis, Faculty of Economic, Batina University, Algeria.

Stanescu, S. G., Ionesco, C. A., \& Coman, M. D. (2020). Environmental Audit Contribution to the Evaluation and Control of Environmental Information. LUMEN Proceedings, 10, 200-213. https://doi.org/10.18662/lumproc/gidtp2018/23

Zu'bi, N., Ali, A., Zu'bi, N., Zahran, A., \& Daraghmeh, Z. (2006). Toward the Application of Environmental Auditing in Jordan, Derasat (Administrative Sciences), 33(1), 1-16.

\section{Copyrights}

Copyright for this article is retained by the author(s), with first publication rights granted to the journal.

This is an open-access article distributed under the terms and conditions of the Creative Commons Attribution license (http://creativecommons.org/licenses/by/4.0/). 